\title{
ADVANTAGES AND PITFALLS OF SOUTH AFRICA-ANGOLA STRATEGIC ALLIANCES
}

\author{
Dr A.J. Vögel: University of Pretoria \\ Mr G.B.L. Pires da Cunha: University of Pretoria
}

Purpose: Owing to a shortage of South African research focusing on international strategic alliances, this study aimed to determine whether the advantages and pitfalls of international strategic alliances referred to in international business publications are also applicable to South African international strategic alliances.

Design/Methodology/Approach: This was a formal, empirical study that targeted the 163 South African enterprises which were members of the South African-Angolan Chamber of Commerce in 2005 and 2006.

Findings: The results identified joint ventures as the most prominent mode of entry when expanding into developing countries and, with few exceptions, the findings support the advantages and pitfalls of international strategic alliances identified in other international publications.

Value of the research: A great deal of international management research over the years has been focused on the importance of strategic alliances as a mode of entry, as well as on the pitfalls experienced by alliance partners, particularly in developed countries. However, the lack of such research in Africa in general and South Africa in particular means that South African enterprises must base their entry mode selection on non-South African research findings, and although this sample size was small, the lack of other Africaspecific research makes this research significant.

Implications: With South Africa being the largest source of FDI into the rest of Africa, the findings of this paper show that South African enterprises can attain the advantages associated with international strategic alliances when using this mode of entry into Africa. In terms of pitfalls, the findings highlight the need for multinational enterprises to pay specific attention to the role of governments when forming strategic alliances.

Key words and phrases: International strategic alliance, strategic alliance, entry mode selection, joint ventures.

\section{INTRODUCTION AND PROBLEM STATEMENT}

As it is increasingly difficult to build and maintain a competitive advantage in the global economy, many enterprises are turning to strategic alliances to help them do so (Townsend, 2003: 143; Gonzalez, 2001: 47; Morrison \& Mezentseff, 1997: 351). Cavusgil (1998: 92) supports this view by stating that with increased globalisation, competitive intensity, risk and uncertainty, many enterprises have recognised the need to collaborate in order to compete abroad. Or as stated by Kauser and Shaw (2004: 17), managers are realising that, no matter how strong and resourceful their enterprise might be, they are no longer able to maintain a competitive advantage at every step in the value chain in all national markets, nor are they able to maintain a cutting edge in the wide range of technologies required for the design, development, manufacture and marketing of new products.

The importance of strategic alliances is highlighted by Harbison and Pekar (in Townsend, 2003: 143), who state that over 20000 new alliances were formed between 1987 and 1992, while according to Oster (in Chen, 2003: 758), over 500 alliances were formed between Japanese enterprises and enterprises in the United States (US) between 1980 and 1990.

Mockler (1999: 1) defines the term strategic as "important" and alliance as "association of interest". As a result strategic alliances can be seen as an association important to alliance partners and formed to further their common interests. More specifically, the term 'international strategic alliance' can be defined, according to Parkhe (in Mellahi, Frynas and Finlay, 2005: 211), as a relatively enduring inter-enterprise cooperative 


\section{Dr A.J. Vögel, Mr G.B.L. Pires da Cunha}

arrangement, involving cross-border flows and linkages that utilise resources and/or governance structures from autonomous organisations headquartered in two or more countries, for the joint accomplishment of individual goals linked to the corporate mission of each sponsoring enterprise. Deresky (2002: 261) supports this definition by defining global strategic alliances as working partnerships between enterprises (often more than two) across national boundaries and increasingly across industries.

Apart from gaining a competitive advantage, enterprises can pursue international strategic alliances for numerous other reasons, such as, sharing risks, gaining access to new markets and reducing costs (Gonzalez, 2001: 47; Townsend, 2003: 147; Cavusgil, 2001: 92 Mockler, 1999: 6; Jagersma, 2005: 42).

However, enterprises do not always realise these advantages. According to Gonzalez (2001: 48), 70 percent of alliances fail, while Levine and Byrne (in Klein \& Dev, 1997) suggest that 70 percent of joint ventures either fall short of expectations or are disbanded. One particular study has found that although the 15 most successful alliances increased shareholder value by US $\$ 72$ billion, the 15 least successful alliances decreased market capitalisation by US\$ 43 billion (Gonzalez, 2001: 48).

Looking at emerging markets, Keitt (in Cavusgil, 2001: 92) states that emerging markets are growing faster than post-industrial economies and offer more lucrative opportunities. This statement is echoed by $\mathrm{De}$ Mattos, Sanderson and Ghauri (2002: 701-702) when stating that the big emerging markets such as China, Brazil, Turkey, India and Mexico are increasing their importance in the global economic environment, and according to Govindarajan and Gupta (in De Mattos et al, 2002: 701), the world's economic centre of gravity will shift towards these emerging countries in the next 20 years. The increasing importance of emerging markets is further supported by the World Economic Forum which has stated that the European Union's share of total global output will shrink from 18 percent in 2004 to ten percent in 2050, while that of Japan will decline from eight percent to four percent. In solving this problem the World Economic Forum suggests among other things that developed countries should set up more businesses in the developing world (European Intelligence Wire, 2004). This is of particular importance in view of the fact that enterprises are increasingly entering into partnerships with foreign enterprises as global markets become more attractive and domestic markets remain stagnant.

However, most of the international management research originates in the USA and Europe (Lau, 2002: 171; Tsui, 2004: 492), while the majority of research on international strategic alliances tends to focus on, or originate in the US, Europe, and Asia (Narula \& Hagedoorn, 1999: 286-287; Bleeke \& Ernst, 1995: 98; Kauser \& Shaw, 2004: 27; Nielsen, 2007: 347; Kotabe et al, 2000). From a South African point of view very little research is done on international strategic alliances, with research on strategic alliances either focused on alliances between South African enterprises (Ahwireng-Obeng \& Egunjobi, 2001: 44), general strategic alliance issues not specific to South Africa (Klein \& Dev, 1997) or on South Africa-US joint ventures (Akande \& Banai, 2009).

The lack of research on strategic alliances between South African enterprises and specifically enterprises in the rest of Africa is significant. South Africa was the largest investor into the rest of Africa during the period 1990 to 2000 (averaging around US\$1.4bn per year, or roughly \$12.5bn in total over the decade), with most of the investments made in the second half of the 1990s. South African enterprises are gathering pace, moreover, making more new investments in African in the period 2001-2003 than in the five years to 2000 (South Africa Foundation, 2004: 13, 16). 
As a result of the lack of research on international strategic alliances in South Africa, this exploratory research was aimed at gaining a better understanding of the topic and in particular of the extent to which South African enterprises are realising the advantages or experiencing the pitfalls associated with alliances. In particular strategic alliances between South African and Angolan enterprises were chosen as starting point for this research, because:

- Angola is a member of the Southern African Development Community (SADC) (SADC, 2009; Department of Trade and Industry, n.d.).

- Angola is considered to have one of the highest growth rates in the world at 18.6 percent (World Bank, 2007) or 20.8 percent according to the British Foreign and Commonwealth Office (n.d.).

- Angola consistently ranks among the top ten recipients of foreign direct investment (FDI) in Africa (see Table 1) (UNCTAD, 2005: 8).

- According to the British Foreign and Commonwealth Office (n.d.), Angola is considered a difficult country to invest in because of excessive bureaucracy. One of the often cited reasons for making use of international strategic alliances is the fact that the local partner's knowledge of the government and government systems can help you overcome this obstacle (Griffin \& Pustay, 2002: 348; Hill, 2007: 499).

As stated earlier, most of the focus on international strategic alliances has come from the US, Europe and Asia (Narula \& Hagedoorn, 1999: 286-287; Bleeke \& Ernst, 1995: 98; Kauser \& Shaw, 2004: 27; Nielsen, 2007: 347), while very little has been done in South Africa - a statement supported by Akande and Banai (2009:2). When looking at other international management issues such as expatriate failure, research has proved that what is known about the US cannot necessarily be generalised to the rest of the world and in particular South Africa. As an example, according to the literature the expatriate failure rate in the US can range between 10 and 80 percent, with a common failure rate ranging between 30 and 40 percent (Briscoe \& Schuler, 2004: 243-244; Shay \& Tracey, 1997: 31; Tung, 1982: 68). In South Africa, however, the failure rate ranges between 2 and 40 percent (Muller in Sapa, 2004; Hawley in Van Aswegen, 2008: 3; Van Heerden \& Wentzel in Van Aswegen, 2008: 3). If this is true for expatriate failure, we might not be able to generalise the advantages and the pitfalls of international strategic alliances to South African international strategic alliances.

Table 1: Top ten recipients of Foreign Direct Investment, 1999-2003 (Million Dollars)

\begin{tabular}{|c|c|c|c|c|c|c|c|c|c|}
\hline \multicolumn{2}{|l|}{1999} & \multicolumn{2}{|l|}{2000} & \multicolumn{2}{|l|}{2001} & \multicolumn{2}{|l|}{2002} & \multicolumn{2}{|l|}{2003} \\
\hline Country & Value & Country & Value & Country & Value & Country & Value & Country & Value \\
\hline Angola & 2471 & Egypt & 1235 & $\begin{array}{l}\text { South } \\
\text { Africa }\end{array}$ & 6789 & Angola & 1643 & Morocco & 2279 \\
\hline South Africa & 1502 & Nigeria & 930 & Morocco & 2825 & Nigeria & 1281 & $\begin{array}{l}\text { Equat. } \\
\text { Guinea }\end{array}$ & 1431 \\
\hline Egypt & 1065 & $\begin{array}{l}\text { South } \\
\text { Africa }\end{array}$ & 888 & Angola & 2146 & Algeria & 1065 & Angola & 1415 \\
\hline Nigeria & 1005 & Angola & 879 & Algeria & 1196 & Chad & 1030 & Sudan & 1349 \\
\hline Morocco & 850 & Tunisia & 779 & Nigeria & 1104 & Tunisia & 821 & Nigeria & 1200 \\
\hline Tanzania & 542 & Algeria & 438 & $\begin{array}{l}\text { Equat. } \\
\text { Guinea }\end{array}$ & 931 & $\begin{array}{l}\text { South } \\
\text { Africa }\end{array}$ & 757 & Chad & 837 \\
\hline Algeria & 507 & Sudan & 392 & Sudan & 574 & Sudan & 713 & $\begin{array}{l}\text { South } \\
\text { Africa }\end{array}$ & 762 \\
\hline Congo & 491 & Tanzania & 282 & Egypt & 510 & Egypt & 647 & Libya & 700 \\
\hline Mozambique & 382 & Mauritius & 277 & Tunisia & 486 & Morocco & 481 & Algeria & 634 \\
\hline Sudan & 371 & Uganda & 275 & Tanzania & 467 & Botswana & 405 & Tunisia & 584 \\
\hline
\end{tabular}

Source: UNCTAD (2005: 8) 


\section{Dr A.J. Vögel, \\ Mr G.B.L. Pires da Cunha}

In order to gain an insight into South African international strategic alliances in general and strategic alliances with Angolan enterprises in particular, this paper will first focus on the research objectives and literature review in order to determine the stated hypotheses and motivation for the hypotheses. Next the findings of the empirical research will be discussed, followed by the implications of and recommendations from the research.

\section{RESEARCH OBJECTIVES AND LITERATURE REVIEW}

According to Garcia-Canal, Duarte, Criado and Llaneza (2002: 91-92), enterprises can use 17 modes of entry when entering new markets, most of them strategic alliances like licensing, franchising and joint ventures. Traditional forms of entry, particularly those based on financial ownership and tight control, are, however, being replaced by partnerships based on the complementarity of resources and skill, mutual trust, and on the ongoing development of business relationships (De Mattos et al, 2002: 702).

Alliances in particular fall into two broad categories: contractual (non-equity) and equity-based (Peng, 2006: 255; Hill, 2007: 499; Beamish, Morrison \& Rosenzweig, 2000: 113). Contractual alliances entail a relatively low level of commitment, are often limited in scope and duration and may include the following (Peng, 2006: 255):

- Co-marketing

- Research and development contracts

- Turnkey projects

- Strategic suppliers

- Strategic distributors

- Licensing/franchising

Equity-based alliances, however, call for a higher level of commitment and may include (Peng, 2006: 255):

- Strategic investment

- Cross shareholding

- Joint ventures

The use of joint ventures in particular is increasingly becoming an attractive option because, according to Ball et al (2006: 437) and, Griffin and Pustay (2002: 347), in the recent past, numerous governments of developing nations have passed laws requiring local majority ownership for the purpose of giving control of enterprises within their borders to their own citizens. One such law was passed by the Zimbabwean government on 26 September 2007, giving local owners majority control of foreign-owned enterprises (Dzirutwe, 2007). The importance of joint ventures as a form of strategic alliance also becomes evident when we consider that a great deal of research (Beamish, 1987; Lu \& Beamish, 2006; Selekler-Göksen \& UysalTezölmez, 2007) focuses specifically on joint ventures as a form of strategic alliance. In addition, Beamish (1987: 23) found that joint ventures and not wholly-owned subsidiaries are the dominant mode of entry used by multinational enterprises in less developed countries. As joint ventures are receiving so much attention, it is hypothesised that:

$\mathrm{H}_{01}$ : Joint ventures are not the most frequently used form of international strategic alliance between South African and Angolan enterprises.

$\mathrm{H}_{\mathrm{A} 1}$ : Joint ventures are the most frequently used form of international strategic alliance between South African and Angolan enterprises.

The advantages of strategic alliances have been well documented over the years and normally include any number of the following (Gonzalez, 2001: 47; Townsend, 2003: 147; Cavusgil, 2001: 92; Mockler, 1999: 6; Jagersma, 2005: 42; Varadarajan \& Cunningham, 1995: 285): 
- Operational efficiencies, by focusing on an enterprise's core business

- Providing access to new markets, some of which might otherwise be closed to an enterprise

- Allowing for the sharing of risks, whether political or commercial

- The sharing of research and development costs

- Helping to reduce the cost and time of accessing new markets as well as bringing new products to market

- Offering an alternative to mergers and acquisitions

- Helping to broaden a product line or fill product line gaps

- Helping to create or raise barriers to entry into a market

- Gaining new knowledge/skills from alliance partners

In a study focused on enterprises from emerging Latin America, Kotabe et al, 2000: 120-123) identified the following as the main motivations for making use of strategic alliances:

- Access to a foreign partner's technical expertise

- Access to a foreign partner's marketing expertise

- Access to a foreign partner's financial resources

- Direct access to foreign markets

- Risk and cost reduction

- Blocking or co-opting of potential competitors

According to Garcia-Canal et al (2002: 91), one of the main advantages of using alliances is that an enterprise can avoid the need to accumulate its own experience, as proposed by the internationalisation process model of Johnson and Wiedersheim-Paul and Johanson and Vahlne (in Garcia-Canal et al, 2002:91). By setting up an alliance with a local partner an enterprise can speed up its entry into the local market.

However, according to Rice (in Noble, Stafford \& Reger, 1995: 145-146) a study of strategic alliances between Silicon Valley and Asian enterprises has found that more than 95 percent of such alliances fail to meet their target objectives. In a study by Bleeke and Ernst (1991: 127) it was found that two-thirds of the 49 cross-border strategic alliances studied ran into serious managerial or financial trouble within the first two years. However, of the 49 alliances 51 percent were successful for both partners and 33 percent resulted in failure for both. As it is clear from the literature that strategic alliances do not always deliver on their intended advantages or objectives, it was hypothesised that:

$\mathrm{H}_{02}$ : South African enterprises have not obtained the advantages associated with international strategic alliances through their alliances with Angolan enterprises.

$\mathrm{H}_{\mathrm{A} 2}$ : South African enterprises have obtained the advantages associated with international strategic alliances through their alliances with Angolan enterprises.

According to Jagersma (2005: 41), many enterprises have avoided cross-border alliances because of the difficulties inherent in successfully negotiating, managing and exploiting them to achieve an enterprise's strategic objectives. Some of the most often cited reasons for the failure of alliances are (Kauser \& Shaw, 2004: 18; Klein \& Dev, 1997; Cavusgil, 2001: 93):

- Unrealistic expectations of the alliance partners

- The alliances becoming too expensive to maintain

- The incompatibility of alliance partners due to poor partner selection

- A lack of foreign government and market knowledge

- Poor communication between alliance partners 
Dr A.J. Vögel,
Mr G.B.L. Pires da Cunha

Conducting research which included 106 face-to-face and 86 telephone interviews among chief executives and top managers of 89 European, North American and Asian enterprises, Jagersma (2005: 48) identified ten pitfalls of cross-border alliances:

- The failure to agree explicitly on objectives and vision

- An unrealistic outlook on market trends and synergy value embedded in an unrealistic or incomplete business plan

- An overly complex alliance management and organisational structure

- Unclear division of responsibility between partners

- Poor communication between partners embedded in cultural incompatibility

- Inflexibility of the alliance agreement, e.g. no capability to evolve

- The failure to develop the right amount of trust among partners

- A significant overestimation of the synergies and an underestimation of the required investment

- Insufficient resources dedicated to alliance management

- Emphasis on legal safeguards rather than cooperation

Mitigating the risk of failure in any partnership is a critical requirement for success in a global economy (Gonzalez, 2001: 48). In the light of the disadvantages/pitfalls of international strategic alliances it was hypothesised that:

$\mathrm{H}_{03}$ : South African enterprises are not facing the disadvantages/pitfalls associated with international strategic alliances through their strategic alliances with Angolan enterprises.

$\mathrm{H}_{\mathrm{A} 3}$ : South African enterprises are facing the disadvantages/pitfalls associated with international strategic alliances through their strategic alliances with Angolan enterprises.

\section{METHODOLOGY}

The following methodology was used in testing the hypotheses.

\section{The sample}

Non-probability judgment sampling was used, as only South African MNEs with strategic alliances in Angola were included in the study. The research targeted the 163 South African enterprises which were members of the South African-Angolan Chamber of Commerce in 2005 and 2006. Over the two years the South African enterprises' representatives at the Chamber of Commerce were approached, in some cases receiving eight electronic questionnaires, two faxed questionnaires, personal visits and discussions at two conferences. However, only 65 questionnaires were returned, of which 35 indicated that they were involved in a strategic alliance with an Angolan partner. The small sample size seems to be supported by the South Africa Foundation (2004: 13), which stated in a recent report on South Africa's business presence in Africa that it has proved to be difficult to obtain information on South Africa's investment into the rest of Africa.

\section{Measurement instrument}

The research was started with a literature study of the international strategic alliance literature in order to identify the most frequently cited advantages and disadvantages/pitfalls of international strategic alliances. Based on this information a questionnaire was designed consisting of the following:

- A qualifying question - in order to determine if the enterprise made use of strategic alliances in Angola.

- Six demographic questions.

- In order to determine the main reasons for choosing Angola as a market to expand into eight questions on a four-point Likert-type scale were used, as well as one open-ended question to elicit any other reasons not provided for in the previous questions.

- The advantages of the strategic alliances with Angolan enterprises were tested using ten questions on a four-point Likert-type scale and one open-ended question for other answers. 


\author{
Dr A.J. Vögel, \\ Mr G.B.L. Pires da Cunha
}

- Lastly the disadvantages/pitfalls of the strategic alliances were measured by ten questions measured on a four-point Likert-type scale and one open-ended question for other answers not provided for in the other ten questions.

\section{Statistical analysis of the data}

The reliability of the measurement instrument was tested using Cronbach's Alpha. Three factors were identified, namely reasons for entering the Angolan market (Cronbach Alpha 0.85); advantages of strategic alliances (Cronbach Alpha 0.93); and disadvantages of strategic alliances (Cronbach Alpha 0.87). As all three factors scored in excess of 0.7 , the measurement can be considered reliable. Due to the relatively small sample size, the study could only progress to the first level of inferential statistics.

\section{RESULTS}

\section{Demographic data}

The single biggest industry represented by these strategic alliances was the construction industry, followed by mining. These findings seem to be in line with, first, the fact that mining, civil engineering and construction, agriculture, tourism and the manufacturing and service industries that feed into them have traditionally dominated the South African economy (South Africa Foundation, 2004: 11); and secondly, the knowledge that Angola has just emerged from a 27-year civil war which raged since independence from Portugal in 1975 (Keeton, 2003; British Foreign \& Commonwealth Office, n.d.), and the fact that the country is rich in oil and natural gas; and that before the civil war it was the fourth biggest source of diamonds in the world (British Foreign \& Commonwealth Office, n.d.; Department of Trade and Industry, n.d.). Of the enterprises in the study, 15 were small (between one and 50 employees) while 14 were large (more than 200 employees). On the question of the duration of the alliance, 25 of the 35 enterprises indicated that they were involved in an alliance with an indefinite duration. Lastly, 27 of the alliances were joint ventures and as a result the hypothesis - Joint ventures are not the most frequently used form of international strategic alliance between South African and Angolan enterprises - could not be accepted but the alternative hypothesis could be. This finding seem to support the new law on private investment enacted by the Angolan government, allowing projects to be undertaken with the participation of both domestic and foreign investors (UNCTAD, 2004: 43).

\section{Reason for entering the Angolan market}

In an attempt to gain a better understanding of the alliances and why Angola was chosen as a destination to expand into, eight questions were included focusing on the reasons for expanding into Angola.

From the information in Table 2 it can be seen that the most prominent reason for entering the Angolan market was the availability of natural and mineral resources - Angola is rich in oil, natural gas and diamonds (British Foreign \& Commonwealth Office, n.d.; Department of Trade and Industry, n.d.). Secondly, the high demand for economic development as well as Angola's transition to a free-market economy served as reasons for expanding into the country. When looking at these findings it becomes evident why the two biggest industries represented by the respondents are the construction and the mining industries. These finding are also supported by Keeton (2003), when stating that there is a significant increase in the number of South Africans visiting Angola in search of opportunities with the civil conflict extinguished, South Africans are making inroads into the infrastructure development, mining and logistics industries. 
Table 2: Reasons for entering the Angolan market

\begin{tabular}{|l|l|l|l|l|l|l|}
\hline Reasons & $\begin{array}{l}\text { Strongly } \\
\text { Agree }\end{array}$ & $\begin{array}{l}\text { Agree } \\
\text { Somewhat }\end{array}$ & $\begin{array}{l}\text { Disagree } \\
\text { Somewhat }\end{array}$ & $\begin{array}{l}\text { Strongly } \\
\text { Disagree }\end{array}$ & $\begin{array}{l}\text { Mean } \\
\text { Score }\end{array}$ & $\begin{array}{l}\text { Std } \\
\text { Deviation }\end{array}$ \\
\hline $\begin{array}{l}\text { The possibility of higher } \\
\text { returns on investment } \\
\text { than in other African } \\
\text { countries. }\end{array}$ & 11 & 3 & 1 & 1.8 & 0.73 \\
\hline Political stability. & 10 & 15 & 9 & 0 & 2.0 & 0.76 \\
\hline $\begin{array}{l}\text { The transition to a free- } \\
\text { market economy. }\end{array}$ & 17 & 15 & 2 & 0 & 1.6 & 0.61 \\
\hline $\begin{array}{l}\text { Angola's potential in } \\
\text { natural and mineral } \\
\text { resources. }\end{array}$ & 12 & 1 & 0 & 1.4 & 0.56 \\
\hline $\begin{array}{l}\text { Angola being a member } \\
\text { of SADC, which } \\
\text { facilitates investment, } \\
\text { market access and } \\
\text { success in Angola. }\end{array}$ & 7 & 14 & 12 & 2 & 2.3 & 0.85 \\
\hline $\begin{array}{l}\text { Geographic proximity to } \\
\text { South Africa. }\end{array}$ & 13 & 16 & 6 & 0 & 1.8 & 0.72 \\
\hline $\begin{array}{l}\text { High purchasing power } \\
\text { in Angola. }\end{array}$ & 10 & 14 & 8 & 2 & 2.1 & 0.89 \\
\hline $\begin{array}{l}\text { High demand for } \\
\text { economic development. }\end{array}$ & 17 & 16 & 2 & 0 & 1.6 & 0.61 \\
\hline
\end{tabular}

These findings also support the findings of the South Africa Foundation (2004: 18) that the African countries that have undergone substantial (positive) political and regulatory reforms have attracted the most investment from South African enterprises. The foundation did, however, find that in Angola investment is largely "enclave investments" occurring outside of trouble spots.

Our research further supports the finding of the South Africa Foundation (2004: 10) that proximity and familiarity with both products and conditions have traditionally been important considerations for South African enterprises when choosing markets to expand into.

Considering the success of trade blocs (regional economic integration) such as the European Union (EU) and the North American Free Trade Agreement (NAFTA) (Hough \& Neuland, 2007: 44, 50), it is interesting to note that the fact that Angola is a member of SADC was the least important reason for the South African enterprises to enter Angola.

\section{Advantages of International Strategic Alliances}

From the information in Table 3 it can be seen that the South African enterprises are realising the advantages associated with strategic alliances with their Angolan alliance partners. The biggest advantage of these alliances was found to be the fact that the alliances helped to ease entry into the Angolan market, followed by helping the South African enterprises gain a competitive advantage, and gaining a better understanding of how to deal with managing business conflict in Angola. 
Table 3: Advantages of strategic alliances

\begin{tabular}{|l|l|l|l|l|l|l|}
\hline Advantages & $\begin{array}{l}\text { Strongly } \\
\text { Agree }\end{array}$ & $\begin{array}{l}\text { Agree } \\
\text { Somewhat }\end{array}$ & $\begin{array}{l}\text { Disagree } \\
\text { Somewhat }\end{array}$ & $\begin{array}{l}\text { Strongly } \\
\text { Disagree }\end{array}$ & $\begin{array}{l}\text { Mean } \\
\text { Score }\end{array}$ & $\begin{array}{l}\text { Std } \\
\text { Deviation }\end{array}$ \\
\hline $\begin{array}{l}\text { Eases the entry into the } \\
\text { Angolan market. }\end{array}$ & 20 & 12 & 2 & 0 & 1.5 & 0.61 \\
\hline $\begin{array}{l}\text { Enables enterprises to } \\
\text { share investment risks. }\end{array}$ & 11 & 12 & 11 & 1 & 2.1 & 0.87 \\
\hline $\begin{array}{l}\text { Shared knowledge and } \\
\text { expertise are obtained } \\
\text { through strategic } \\
\text { alliances. }\end{array}$ & 17 & 13 & 4 & 1 & 1.7 & 0.80 \\
\hline $\begin{array}{l}\text { Helps to attain a } \\
\text { competitive advantage. }\end{array}$ & 20 & 11 & 3 & 1 & 1.6 & 0.78 \\
\hline $\begin{array}{l}\text { Enables an enterprise to } \\
\text { realise higher returns on } \\
\text { investment. }\end{array}$ & 12 & 14 & 8 & 1 & 1.9 & 0.84 \\
\hline $\begin{array}{l}\text { Enables an enterprise to } \\
\text { attract loyal customers. }\end{array}$ & 8 & 15 & 10 & 2 & 2.2 & 0.86 \\
\hline $\begin{array}{l}\text { Greater operational } \\
\text { efficiencies. }\end{array}$ & 9 & 17 & 8 & 1 & 2.0 & 0.79 \\
\hline $\begin{array}{l}\text { Facilitates the formation } \\
\text { of long-term relationships } \\
\text { with Angolan partners. }\end{array}$ & 16 & 13 & 5 & 1 & 1.7 & 0.83 \\
\hline $\begin{array}{l}\text { Allows enterprises to get } \\
\text { products to the market } \\
\text { more efficiently. }\end{array}$ & 13 & 13 & 3 & 2 & 1.9 & 0.87 \\
\hline $\begin{array}{l}\text { Facilitates an } \\
\text { understanding of how to } \\
\text { manage business conflict } \\
\text { in Angola. }\end{array}$ & 18 & 15 & & 1.6 & 0.77 \\
\hline
\end{tabular}

The least important advantage identified was the ability of the alliance to attract loyal customers of the Angolan partner to the new alliance, followed by the strategic alliance's ability to allow the alliance partners the opportunity to share investment risks.

As the respondents in the majority of cases indicated that they had obtained the advantages associated with strategic alliances, the hypothesis - South African enterprises have not obtained the advantages associated with international strategic alliances through their alliances with Angolan enterprises - is not accepted, but the alternative hypothesis is accepted.

\section{Disadvantages/Pitfalls}

From the information in Table 4 it can be seen that the biggest problems experienced by the South African enterprises were not associated with the alliance itself but rather with government issues of the chosen alliance partner country (Angola). From the data it can be seen that the lack of implementation of legislation to protect investments was the biggest pitfall, followed by the fact that the lack of infrastructure negatively influences the performance of the alliance. 
Dr A.J. Vögel,

Mr G.B.L. Pires da Cunha

Table 4: Disadvantages/Pitfalls of strategic alliances

\begin{tabular}{|c|c|c|c|c|c|c|}
\hline Disadvantages/Pitfalls & $\begin{array}{l}\text { Strongly } \\
\text { Agree }\end{array}$ & $\begin{array}{l}\text { Agree } \\
\text { Somewhat }\end{array}$ & $\begin{array}{l}\text { Disagree } \\
\text { Somewhat }\end{array}$ & $\begin{array}{l}\text { Strongly } \\
\text { Disagree }\end{array}$ & $\begin{array}{l}\text { Mean } \\
\text { Score }\end{array}$ & $\begin{array}{l}\text { Std } \\
\text { Deviation }\end{array}$ \\
\hline $\begin{array}{l}\text { Differences in alliance } \\
\text { goals }\end{array}$ & 7 & 16 & 8 & 3 & 2.2 & 0.88 \\
\hline $\begin{array}{l}\text { Difficulty in accessing } \\
\text { reliable and important } \\
\text { information from partners }\end{array}$ & 9 & 14 & 9 & 3 & 2.2 & 0.92 \\
\hline $\begin{array}{l}\text { Distribution of earnings } \\
\text { between parties }\end{array}$ & 6 & 10 & 9 & 9 & 2.6 & 1.07 \\
\hline Loss of autonomy & 2 & 11 & 14 & 7 & 2.8 & 0.85 \\
\hline $\begin{array}{l}\text { Economic and } \\
\text { technological conditions in } \\
\text { Angola affecting the } \\
\text { viability of the alliance }\end{array}$ & 6 & 17 & 8 & 4 & 2.3 & 0.89 \\
\hline Cultural difference & 7 & 19 & 7 & 2 & 2.1 & 0.80 \\
\hline $\begin{array}{l}\text { Lack of ongoing } \\
\text { commitment (time, money } \\
\text { and people) from the } \\
\text { alliance partner }\end{array}$ & 8 & 15 & 9 & 3 & 2.2 & 0.90 \\
\hline $\begin{array}{l}\text { Insufficient attention being } \\
\text { paid to the financial } \\
\text { aspects of the alliance by } \\
\text { the alliance partner }\end{array}$ & 7 & 12 & 9 & 5 & 2.4 & 0.99 \\
\hline $\begin{array}{l}\text { Poor infrastructure } \\
\text { affecting the positive } \\
\text { performance of the alliance }\end{array}$ & 10 & 17 & 5 & 2 & 2.0 & 0.83 \\
\hline $\begin{array}{l}\text { Insufficient implementation } \\
\text { of legislation to protect } \\
\text { investment }\end{array}$ & 12 & 15 & 5 & 1 & 1.8 & 0.80 \\
\hline
\end{tabular}

Very interestingly, the data has shown that the least important disadvantage/pitfall of these alliances was the loss of autonomy for alliance partners, followed by the fact that the distribution of earning between alliance partners does not seem to be a major concern.

From the findings in Table 4 it can be seen that the respondents are in the majority of cases in agreement with the fact that they are experiencing the disadvantages/pitfalls normally associated with strategic alliances. As result of this finding the alternative hypothesis - South African enterprises are facing the disadvantages/pitfalls associated with international strategic alliances through their strategic alliances with Angolan enterprises - is accepted.

\section{CONCLUSION}

A great deal of international management research over the years has been focused on the importance of strategic alliances as a mode of entry as well as on the pitfalls experienced by alliance partners, particularly in developed countries. In fact the research has progressed far beyond this point to focus on partner selection, structuring an alliance and measuring alliance success. However, the lack of such research in Africa in general and South Africa in particular means that South African enterprises must base their entry mode selection on non-South African research findings, and although this sample size was small and the list of advantages and disadvantages was not exhaustive, the lack of Africa-specific research makes this research significant. 


\author{
Dr A.J. Vögel, \\ Mr G.B.L. Pires da Cunha
}

The findings of this research predominantly support other international studies on strategic alliances, with very few exceptions. In particular it was found that strategic alliances help to ease the entry into Angola, one of the 50 least developed countries in the world (UN-OHRLLS, n.d.). As South Africa is the single biggest source of FDI into Africa (South Africa Foundation, 2004: 13), this is of particular interest to South African enterprises, as 33 of the 50 least developed countries are in Africa (UN-OHRLLS, n.d.). The strengthening of ties between the governments of South Africa and Angola with the signing of three new agreements - a petroleum sector agreement, a tourism agreement, and an intent to waive visas for ordinary passport holders (Department of Foreign Affairs, 2007) - on 22 November 2007 has further highlighted the importance of research on cooperation between enterprises from these two nations as well as entry mode selection into Angola in particular.

Significantly, this research seems to still support the 1984 findings of Lev and Hacker (in Cavusgil, 2001: 93), who stated that many enterprises fail to assess the effect of government intervention in foreign investment practices. As indicated earlier, the biggest disadvantages/pitfalls of the strategic alliances in this research were associated with the insufficient implementation of legislation and poor infrastructure, both governmental issues. Recent research by Akande and Banai (2009: 9) seems to suggest that this is not just an Angolan problem, as US enterprises involved in US-South Africa joint ventures identified the volatility of government regulations as one of the biggest problems facing their alliances.

It was also found that the possible loss of autonomy was the least important disadvantage/pitfall experienced by the South African enterprises. As the potential loss of autonomy is listed by other authors (Griffin \& Pustay, 2002: 360) as a possible disadvantage/pitfall of strategic alliances, future research should focus on how these South African alliances are structured in order to determine what other enterprises could learn from them in order to overcome this pitfall.

The research also found that the fact that Angola is a member of the SADC was the least important reason for choosing Angola as a market to expand into. This was of particular interest given the fact that other trade blocs such as the EU and NAFTA are seen to be successful in promoting trade and investment between countries in these blocs (Hough \& Neuland, 2007: 44, 50). One possible reason for this finding might be that African countries have been struggling to establish a political identity, and the different trade groups have political as well as economic underpinnings (Daniels, Radebaugh \& Sullivan, 2007: 293-294). In support of Daniels et al (2007: 293-294), it should be noted that the SADC was formerly known as the Southern African Development Co-ordination Conference (SADCC)(1980-1992), which had as one of its objectives the reduction of member states' dependence on apartheid South Africa. While Angola was a member, South Africa only became a member in 1992 (SADC, 2006). As a result of this finding it might be of value to determine the value of the SADC to enterprises within the region.

Lastly, the findings indicated that there seemed to be a justified focus on joint ventures in the international management research, as joint ventures are by far the most used form of strategic alliance between these two countries. As indicated earlier, these findings are in line with the fact that the Angolan government enacted a new law on private investment allowing projects to be undertaken with the participation of both domestic and foreign private investors (UNCTAD, 2004: 43). These findings also support the findings of Beamish (1987: 23), that joint ventures were the dominant mode of entry used by multinational enterprises in less developed countries. With African nations - Zimbabwe in particular - wishing to give local owners majority control of foreign-owned enterprises, this mode of entry seems to be set to increase in importance in Africa, and as a result it warrants more research, specifically from an African perspective.

\section{IMPLICATIONS}

It is a well-known fact that South Africa has for decades been isolated politically, economically, socially and in more extreme cases, even physically from much of the rest of the world. However, since the mid-to late- 
1990s, South African enterprises have become far more at home in the international environment - whether they are exporting, importing, investing in other countries or undertaking projects in other countries (South Africa Foundation, 2004:4).

If South African enterprises are thus seen as late starters in the international environment, they will need to use modes of entry that will speed up their entry into foreign markets. According to Garcia-Canal et al (2002), the internationalisation process model sees the internationalisation of an enterprise as a process in which the enterprise gradually increases its commitment of resources to foreign markets as it gains knowledge about the foreign market (Garcia-Canal et al, 2002; Johanson \& Vahlne, 1990:11). However, using strategic alliances can ease entry into a foreign market with the help of a local partner. The findings of this study support this view by showing that strategic alliances not only help to ease the entry into a new market, but also facilitate an understanding of how to manage business conflict in Angola.

As the study identified the insufficient implementation of legislation to protect investments as the biggest pitfall of the SA-Angola strategic alliances, enterprises should pay specific attention to their choice of alliance, a fact further highlighted by Angola's corruption index rankings 119 out of 179 countries (World Audit, 2007) and 158 out of 180 countries (Transparency International, 2008). As a result, enterprises should focus on alliances that would reduce their exposure to risk. 


\section{REFERENCES}

Ahwireng-Obeng, F. \& Egunjobi, O.O. 2001. Performance determinants of large-small business strategic alliances in South Africa. South African Journal of Business Management, 32(1): 41-50.

Akande, W.A. \& Banai, M. 2009. Your next boss is American: Attitudes of South African managers towards prospective US-South African joint ventures. South African Journal of Business Management, 40(2): 1-13.

Ball, D.A., McCulloch, Jr., W.H., Frantz, P.L., Geringer, J.M. \& Minor, M.S. 2006. International Business: The challenges of global competition. 10th ed. New York: McGraw-Hill Irwin.

Beamish, P.W. 1987. Joint ventures in LDC's: Partner selection and performance. Management International Review, 27(1): 23-37.

Beamish, P.W., Morrison, A.J., Rosenzweig, P.M. \& Inkpen, A.C. 2000. International management: Text and cases. 4th ed. Boston: Irwin McGraw-Hill.

Bleeke, J. \& Ernst, D. 1991. The way to win in cross-border alliances. Harvard Business Review, NovemberDecember: 127-135.

Bleeke, J. \& Ernst, D. 1995. Is your strategic alliance really a sale? Harvard Business Review, JanuaryFebruary: 97-105.

Briscoe, D.R. \& Schuler, R.S. 2004. International human resource management. 2nd ed. London: Routledge Taylor \& Francis Group.

British Foreign and Commonwealth Office. n.d. Country profile: Angola. [Online] Available from: http://www.fco.gov.uk/servlet/Front?pagename=OpenMarket/Xcelerate/ShowPage\&c=Page\&cid=100702939 4365\&a=KCountryProfile\&aid=1019501109024 [Accessed: 2007-10-31].

Cavusgil, S.T. 1998. Executive insight: International partnering - A systematic framework for collaborating with foreign business partners. Journal of International Marketing, 6(1): 91-107.

Chen, Z. 2003. A theory of international strategic alliances. Review of International Economics, 11(5): 758769.

Daniels, J.D., Radebaugh, L.H. \& Sullivan, D.P. 2007. International Business: Environment and operations. $11^{\text {th }}$ ed. Upper Saddle River: Pearson Prentice Hall.

De Mattos, C., Sanderson, S. \& Ghauri, P. 2002. Negotiating alliances in emerging markets: Do partners' contributions matter? Thunderbird International Business Review, 44(6): 701-728.

Department of Foreign Affairs. 2007. Minister Dlamini Zuma to meet Angolan President Eduardo dos Santos. [Online] Available from: http://www.dfa.gov.za/docs/2007/ango1121.htm [Accessed: 2007-11-26].

Department of Trade and Industry. n.d. Angola economic overview. [Online] Available from: http://www.thedti.gov.za/econdb/reportt/angolaOverview.htmi [Accessed: 2007-10-31].

Deresky, H. 2002. International management: managing across borders and cultures. 4th ed. Upper Saddle River: Prentice Hall. 


\section{Dr A.J. Vögel, \\ Mr G.B.L. Pires da Cunha}

Dzirutwe, M. 2007. Zimbabwe passes bill to transfer all foreign owned firms to locals. [Online] Available from: http://www.busrep.co.za/index.php?Sectionld=552\&fArticleld=4053389 [Accessed: $2007-09-28$ ].

European Intelligence Wire. 2004. Shrinking workforce to knock economic output in EU, Japan. [Online] Available from: http://web5.infotrac.galegroup.com/itw/infomark/979/215/44353632w5/purl=rc1 GBI [Accessed: 2004-01-22].

Garcia-Canal, E., Duarte, C.L., Criado, J.R. \& Llaneza, A.V. 2002. Accelerating international expansion through global alliances: A typology of cooperative strategies. Journal of World Business, 37: 91-107.

Gonzalez, M. 2001. Strategic alliances: The right way to compete in the $21^{\text {st }}$ century. Ivey Business Journal, 66(1): 47-51.

Griffin, R.W. \& Pustay, M.W. 2002. International business: A managerial perspective. 3rd ed. Upper Saddle River: Prentice Hall.

Hill, C.W.L. 2007. International business: Competing in the global marketplace. 6th ed. New York: McGrawHill Irwin.

Hough, J. \& Neuland, E. 2007. Global business: Environments and strategies. $3^{\text {rd }}$ ed. Cape Town: Oxford Southern Africa.

Jagersma, P.K. 2005. Cross-border alliances: Advice from the executive suite. The Journal of Business Strategy, 26(1): 41-50.

Johanson, J. \& Vahlne, J.E. 1990. The internationalisation of business: Theory and evidence. International Marketing Review, 7(4): 11-24.

Kauser, S. \& Shaw, V. 2004. The influence of behavioural and organisational characteristics on the success of international strategic alliances. International Marketing Review, 21(1): 17-52.

Keeton, C. 2003. Angola headed for post-war boom as S.A. comes on board. [Online] Available from: http://www.businessday.co.za [Accessed: 2004-11-30].

Klein, S. \& Dev, C. 1997. Partner selection in market-driven strategic alliances. South African Journal of Business Management, 28(3): 97-105.

Kotabe, M., Teegen, H., Aulakh, P.S., Coutinho de Arruda, M.C., Santillan-Salgado, R.J. \& Greene, W. 2000. Strategic alliances in emerging Latin America: A view from Brazilian, Chilean, and Mexican companies. Journal of World Business, 35(2): 114-132.

Lau, C. 2002. Asian management research: Frontiers and challenges. Asia Pacific Journal of Management, 19: $171-178$.

Lu, J.W. \& Beamish, P.W. 2006. Partnering strategies and performance of SMEs' international joint ventures. Journal of Business Venturing, 21: 461-486.

Mellahi, K., Frynas, G.J. \& Finlay, P. 2005. Global strategic management. Oxford: Oxford University Press. Mockler, R.J. 1999. Multinational strategic alliances. New York: John Wiley. 


\section{Dr A.J. Vögel, Mr G.B.L. Pires da Cunha}

Morrison, M. \& Mezentseff, L. 1997. Learning alliances - A new dimension of strategic alliances. Management Decision, 35(5): 351-357.

Narula, R. \& Hagedoorn, J. 1999. Innovating through strategic alliances: Moving towards international partnerships and contractual agreements. Technovation, 19: 283-294.

Nielsen, B.B. 2007. Determining international strategic alliance performance: A multidimensional approach. International Business Review, 16: 337-361.

Noble, C.H., Stafford, E.R. \& Reger, R.K. 1995. A new direction for strategic alliance research in marketing: Organizational cognition. Journal of Strategic Marketing, 3: 145-165.

Peng, M.W. 2006. Global strategy. Mason: Thomson South-Western.

SADC. 2006. SADC history, evaluation and current status. [Online] Available from: http://www.sadc.int/about sadc/history.php [Accessed: 2007-12-12].

SADC. 2009. SADC profile. [Online] Available from: http://www.sadc.int/ [Accessed: 2009-11-19].

Sapa. 2004. SA expats less keen to go home than counterparts. [Online] Available from: http://www.pretorianews.co.za/index.php?fSectionld=665\&fArticleld=2106312 [Accessed: 2004-06-14].

Selekler-Göksen, N.N. \& Uysal-Tezölmez, S.H. 2007. Control and performance in international joint ventures in Turkey. European Management Journal, 25(5): 384-394.

Shay, J. \& Tracey, J.B. 1997. Expatriate managers: Reasons for failure and implications for training. Cornell Hotel and Restaurant Administration Quarterly, February: 30-35.

South Africa Foundation. 2004. South Africa's Business Presence in Africa. [Online] Available from: http://www.safoundation.org.za/documents/SABusinessPresenceinAfrica web.pdf [Accessed: 2007-12-7].

Townsend, J.D. 2003. Understanding alliances: a review of international aspects in strategic marketing. Marketing Intelligence and Planning, 21(3): 143-155.

Transparency International. 2008. Corruption perception index. [Online] Available from: http://www.transparency.org/news room/in focus/2008/cpi2008/cpi 2008 table [Accessed: 2009-11-23].

Tsui, A. 2004. Contributing to global management knowledge: A case for high quality indigenous research. Asia Pacific Journal of Management, 21: 491-513.

Tung, R.L. 1982. Selection and training procedures of U.S., European, and Japanese multinationals. California Management Review, 25(1): 57-71.

UNCTAD. 2005. Economic development in Africa: Rethinking the role of foreign direct investment. [Online] Available from: http://www.unctad.org/en/docs/gdsafrica20051 en.pdf [Accessed: 2007-10-9].

UN-OHRLLS. n.d. List of least developed countries. [Online] Available from: http://www.un.org/specialrep/ohrlls/ldc/list.htm [Accessed: 2007-11-26].

Van Aswegen, M. 2008. The establishment of an adjustment model for expatriates. Unpublished DCom thesis. Pretoria: University of Pretoria. 
Dr A.J. Vögel, Mr G.B.L. Pires da Cunha

Varadarajan, P.R. \& Cunningham, M.H. 1995. Strategic alliances: A synthesis of conceptual foundations. Journal of the Academy of Marketing Science, 23(4): 282-296.

World Audit. 2007. Corruption. [Online] Available from: http://www.worldaudit.org/corruption.htm [Accessed: 2009-11-23].

World Bank. 2007. Angola Country Brief. [Online] Available from: http://www.worldbank.org/angola [Accessed: 2007-11-26]. 